\title{
TEACHING PROFESSIONALISM OF HISTOLOGY, CYTOLOGY AND EMBRYOLOGY DEPARTMENT TEACHERS IN ZAPORIZHZHIA STATE MEDICAL UNIVERSITY
}

\section{НАВЧАЛЬНИЙ ПРОФЕСІОНАЛІЗМ ВИКЛАДАЧА КАФЕДРИ ГІСТОЛОГІЇ, ЦИТОЛОГІЇ І ЕМБРІОЛОГІЇ ЗАПОРІЖСЬКОГО ДЕРЖАВНОГО МЕДИЧНОГО УНІВЕРСИТЕТУ}

Резюме. У сучасному суспільстві з його невпинно мінливим способом життя дуже важливого значення набувають високий професіоналізм, професійна компетентність спеціалістів у різних сферах виробничого та суспільного життя. Це стосується й працівників освіти, оскільки викладачі повинні бути професійно компетентними фахівцями в своїй галузі діяльності. Саме через діяльність педагога відбувається становлення громадянина як особистості і фахівця, зміцнюється інтелектуальний і духовний потенціал нації. Нова освітня парадигма, як пріоритетне завдання освіти, передбачає орієнтацію на інтереси особистості, адекватні сучасним тенденціям суспільного розвитку. У зв'язку з цим починає змінюватися статус викладача, його освітні функції. Компетентність спеціаліста в галузі освіти, його професіоналізм набувають дедалі більшого значення, оскільки саме викладач стає основною постаттю в реалізації на практиці будь-яких освітніх нововведень. На сучасному етапі вища освіта вимагає стратегічного управління, особливо на рівні підготовки майбутніх фахівців. Тому формування педагогічного професіоналізму повинно бути основною метою кожного викладача. Викладач вищого навчального закладу повинен постійно працювати над вдосконаленням своєї педагогічної майстерності, від чого безпосередньо залежить досягнення ним професіоналізму.

Ключові слова: професіоналізм, педагогічна майстерність, викладач, вищий навчальний заклад, педагог.

In modern society, with its constantly changing lifestyle it becomes very important to acquire professionalism, professional competence of specialists in different fields of industrial and social life. This is also true of educators as teachers that they should be professionally competent professionals in their field of activity. Through the activities of the teacher the formation of a citizen as a person and professional, strengthening intellectual and spiritual potential of the nation occurs [1].

The new educational paradigm, as a priority task of education provides orientation to the interests of the individual, to the contemporary trends of social development. In this regard, begins to change the status of the teacher, his educational functions. Competence of specialist in education, his professionalism becomes increasingly important, because the teacher is the main figure in the practical implementation of any educational innovation [2].

Increasing importance of higher education for so-cial development has identified new aspects in the understanding of professional training. Continuous innovation processes in education leads to the fact that a high level of knowledge on the subject and possession of studied methodology of teaching may not fully characterize the current level of professional training of teachers. The current situation of social development issues exacerbated the need for further study and clarification of the phenomenon of pedagogical professional educator [3].

Purpose of the study. Detection of professionalism formation of of Histology, Cytology and Embryology department teachers from Zaporizhzhia State Medical University.

Materials and methods. Questionnaires of teachers of Histology, Cytology and Embryology department Zaporizhzhia State Medical University in groups. 1 group - teachers who worked less that 10 years, 2 group - teachers, teaching experience of which is 10-15 years., group 3 - teachers with teach- 
ing expe-rience over 15 years to determine the results of the teachers, the definition of professional development of higher medical educational institution teachers.

Results and discussion. The concept of teacher professionalism varies considerably depending on the educational paradigm, goals of the educational process and ways of achieving them. Typical until recently, traditional paradigm put forward specific requirements for teacher professionalism - high level of knowledge of the taught subject, and the possession of his teaching method.

Modern educational paradigm is based on a different understanding of the concept. Professionalism is expressed in the ability to see and formulate educational objectives based on analysis of teaching situations and finding optimal ways of their solution [3].

A number of regulations on education emphasize the importance of training professionals. Based on the analysis of native and foreign studies S.S. Vitvytska consider professional teacher of high school as an integrated quality, the structure of which is composed of professional knowledge, professional communication, professional self-improvement [4].

S.I. Ivanova binds with high professionalism of teacher skills, I.F. Kharlamov as teaching professional understands brought to a higher level of pedagogical skills. M.A. Vikulin and K.M. Levitin invest in the concept of professionalism the presence of the teacher applied, pedagogical and methodological skills [3].

V.Ya. Sinenko believes that the combination of theoretical knowledge with skills to use them in the educational activity can provide the necessary pedagogical professionalism. M.V. Bulanova-Toporkova believes that the level of professionalism of the teacher depends on the competence and the degree of professional pedagogical thinking. N.V. Kuzmina identifies this notion of two interrelated components: professionalism and expertise of the individual as the personal qualities of the teacher can help or hinder productive solving educational problems. A.K. Markova said that the dominant component of teacher professionalism is his personality [5].

Thus, teaching professional teacher is the ability to see and formulate educational objectives based on theoretical analysis of teaching situations, to find optimal solutions, the ability to self-realization in practice of teaching problem solving new, based on theoretical understanding of learning content, objective psychological and pedagogical characteristics educational process. Teaching professionalism involves a high degree of professional pedagogical competence, acts as an integral quality, the result of professional competence, achievement pedagogical skills [3].

Retrospective theoretical analysis of domestic and foreign literature, allows to define professionalism as an integrated quality, considering that this is the result of intensive long-term educational activities.

Professionalism of the teacher is not formed by external influence on him, and is the result of self education teacher - his work on himself, on his way, on his teaching position, his conscious entry into the culture of the professional community. A new level of professionalism, the ability of the teacher to carry out educational practice that focuses on new values and aims of education is impossible to form at reproductive mode of learning information. These abilities have "grown" in special situations involving direct participation of the teacher [6].

For effective implementation of pedagogical features modern educator is important to understand the basic components of psychological and pedagogical structure of his activities and educational activities, important professional skills and psychological qualities necessary for its implementation.

Young teachers should first learn to design training material, highlight it and most importantly the right to distribute the time that this material is easily perceived by the audience.

Effective training can only be in the study. Therefore, during higher education in the educational process are introduced methods of research activities that teach students the ability to master the methodology of science as a tool for acquiring new knowledge. In view of this institution of higher education teacher becomes a scientist, researcher, theorist and practice leader of student research team, psychologist, educator, manager of training and learning activities of students.

The results of the teachers belong to several levels:

1. Reproductive (insufficient) - is the ability to tell what he knows;

2. Adaptive (low) - provides the ability to tailor their message to the peculiarities of the audience;

3. Locally modeling (Intermediate) - is in possession of teacher knowledge transfer strategies of individual sections and topics;

4. The system-modeling (high) - is the ability to form a system of knowledge and skills of the discipline as a whole;

5. The system-modeling activity and behavior (top) - provides the ability of teachers to convert their subject in a tool for shaping individuality of pupils.

We found that the results of teachers with teaching experience one year to include locally-simulation and system-level modeling, teachers with experience more than a year can be attributed to system-simulation and system-modeling activities and behavior levels. Teachers who taught for 10-15 years are included 
to system-simulation and system-modeling activity and behavior levels. Teachers are working more than 15 years are included to system-modeling activity and behavior levels.

It can be concluded that professionalism of teachers of department is high, because only the fourth and fifth levels are obvious for pedagogical talent, manifested in the ability to subordinate their own interests to pedagogical aim in order to create original system of educational work.

Features of educational activities on medico-biological faculties of higher educational institutions include specific requirements for the individual teacher:

- Awareness of their civic duty - the education of worthy citizens, highly qualified specialists for the national economy.

- Mastery of their academic discipline (experience shows that successfully teaches and educates a teacher who knows his academic disciplines, in addition, a teacher must learn the ropes in related disciplines, which will comprehensively developed expert);

- Mastery of teaching methods, management of teaching and learning activities of students, which helps the teacher to challenge lodge available, consider the characteristics of an individual student interest information, call capture it and wish to supplement their knowledge;

- Pedagogical expression - a kind of installation on educational activities and psychological readiness for it, which turns in the direction of the thoughts and aspirations of the training and education of students;

- Creative approach (teacher who is a creative person, examine and analyze their experiences, studies and uses better with someone else, and is looking for new, advanced, rational public educational technology).

To succeed with students teacher should be focused, proactive, disciplined, demanding of themselves and others.

Equally important in the formation of a professional is appearance of a teacher. Unattractive appearance hateful to him, and thus to the discipline he teaches moral guidance which it promotes [7].

In the development of teacher professionalism can be defined the following level (by S. Barabanova): Student - reproductive (conscious choice of educational institution, education); novice teacher - a practical level (gain experience while working); specialist - search level (maximum arsenal of knowledge, skills, technologies owned by the teacher and the experience of the practical application of knowledge in practice); professional - creative level integration expertise (design their own methods, transfer of experience to other teachers); master - integration of personal maturity and professionalism (master - a teacher who has integrated a professional experience and got a new way to use and transfer of experience) [8].

In terms of teacher professional teachers with experience at least 10 years belonged to the levels of "specialist" and "professional". Teachers who have worked between 10 and 15 years and 15 years up to "professional" and "master".

Conclusions. At the present stage of higher education requires strategic management, especially at the level of training of future professionals. Therefore, the formation of pedagogical professionalism should be the main goal of every teacher. Teacher of higher educational institution must constantly work to improve their pedagogical skills, which depends on attaining his professionalism.

Prospects for further research. We believe that the implementation of innovations in the educational process, to ensure the quality of education needs to be improved, primarily psychological and pedagogical training high school teachers.

Teachers should perceive the students personality, understanding the complexity and diversity of the world, to show their talents and perspectives to create the most favorable conditions for development. Only under such conditions teacher can achieve pedagogical skills, and therefore professionalism.

It is important to understand that in today's professional teacher should manifest itself not only a thorough knowledge of the subject, but also a systematic professional development, creative activity, the ability to efficiently meet the growing demands of society; in personal improvement, including self-education.

In our view, a clear perception of teacher of higher educational establishment of modern educational system will improve not only the effectiveness of teaching natural sciences, but also of the effectiveness of the educational process.

\section{Список використаної літератури}

1. Погоріла С.Г. Педагогічна майстерність викладача ВНЗ - о'бєктивна передумова особистісно зорієнтованого навчання студентів / С.Г. Погоріла // Педагогіка і психологія вищої освіти. - 2007. - № 9. - С. 63-67. 2. Коломієиь С.В. Професіоналізм викладача вищого навчального закладу як фактор вдосконалення навчально- виховного процесу / С.В. Коломієиь // Вісн. Черкаського ун-ту. Серія: Педагогічні науки. - 2009. - № 149. - С. 14-18. 3. Гребенев И.В. Формирование педагогического профессионализма 
в условиях классического университета (На материале подготовки преподавателей физики): автореф. дис. на соискание уч. степени докт. пед. наук : спеи. 13.00.08 "Теория и методика профессионального образования" / Игорь Васильевич Гребенев. - Новгород, 2008. - 45с. 4. Голобородько С.П. Викладач вищого навчального закладу: реалії та перспективи / С.П. Голобородько // Науковий вісник ХДМІ. - 2009.- № 1(1). - С. 61-65. 5. Дуднік О.В. Професійна компетентність та професіоналізм викладача: аналіз змісту та виявлення співвідношення иих категорій у педагогічній научі / О.В. Дуднік // Вісн. ЛНУ імені Тараса Шевченка. - 2011. - Ч. І. - № 15(226). - С. 40-47. 6. Исаев В.Ф. Профессионально-педагогическая культура преподавателя / В.Ф. Исаев. - М.: “Академия”, 2002. - 187 с. 7. Білан Л.Л. Методика викладання у вищій аграрній школі: Навчальний посібник / Л.Л. Білан. - Ніжин: ПП Лисенко, 2010. - 299 с. 8. Проченко О.Б. Акмеологічні засади формування професійної компетентності викладача вищзого навчального закладу / О.Б. Проченко // Наук. вісн. Мелітопольського держ. ун-ту. 2008. - № 12. - C. 295-302.

УЧЕБНЫЙ ПРОФЕССИОНАЛИЗМ ПРЕПО-
ДАВАТЕЛЯ КАФЕДРЫ ГИСТОЛОГИИ, ЦИ-
ТОЛОГИИ И ЭМБРИОЛОГИИ ЗАПОРОЖ-
СКОГО ГОСУДАРСТВЕННОГО МЕДИЦИН-
СКОГО УНИВЕРСИТЕТА

Резюме. В современном обществе с его постоянно меняющимся образом жизни очень важное значение приобретают высокий профессионализм, профессиональная компетентность специалистов в различных сферах производственной и общественной жизни. Это касается и работников образования, поскольку преподаватели должны быть профессионально компетентными специалистами в своей области деятельности. Именно из-за деятельности педагога происходит становление гражданина как личности и специалиста, укрепляется интеллектуальный и духовный потенциал нации. Новая образовательная парадигма, приоритетной задачей образования, предполагает ориентацию на интересы личности, адекватные современным тенденциям общественного развития. В связи с этим начинает меняться статус преподавателя, его образовательные функции. Компетентность специалиста в области образования, его профессионализм приобретают все большее значение, так как именно преподаватель становится основной фигурой в реализации на практике любых образовательных нововведений. На современном этапе высшее образование требует стратегического управления, особенно на уровне подготовки будущих специалистов. Поэтому формирование педагогического профессионализма должно быть основной целью каждого преподавателя. Преподаватель высшего учебного заведения должен постоянно работать над совершенствованием своего педагогического мастерства, от чего напрямую зависит достижения им профессионализма.

Ключевые слова: профессионализм, педагогическое мастерство, преподаватель, высшее учебное заведение, педагог.

\section{TEACHING PROFESSIONALISM OF HISTOLOGY, CYTOLOGY AND EMBRYOLOGY DEPARTMENT TEACHERS IN ZAPORIZHZHIA STATE MEDICAL UNIVERSITY}

Abstract. In modern society, with its constantly changing lifestyle it becomes very important to acquire professionalism, professional competence of specialists in different fields of industrial and social life. This is also true of educators as teachers that they should be professionally competent professionals in their field of activity. Through the activities of the teacher the formation of a citizen as a person and professional, strengthening intellectual and spiritual potential of the nation occurs. The new educational paradigm, as a priority task of education provides orientation to the interests of the individual, to the contemporary trends of social development. In this regard, begins to change the status of the teacher, his educational functions. Competence of specialist in education, his professionalism becomes increasingly important, because the teacher is the main figure in the practical implementation of any educational innovation. At the present stage of higher education requires strategic management, especially at the level of training of future professionals. Therefore, the formation of pedagogical professionalism should be the main goal of every teacher. Teacher of higher educational institution must constantly work to improve their pedagogical skills, which depends on attaining his professionalism.

Key words: professionalism, pedagogical skills, teacher, higher educational institution, educator.

Zaporizhzhia State Medical University (Zaporizhzhia)

Надійшла 10.04.2015 p. Рецензент - проф. Волков К.С. (Тернопіль) 